\title{
Toxicity of Ortho-Phenylphenol (OPP) and Sodium Ortho-Phenylphenate (SOPP)
}

\author{
Orto-Fenilfenol (OPP) ve Sodyum Orto-Fenilfenatın (SOPP) Toksisitesi
}

\section{Selinay Başak ERDEMLİ KÖSE ${ }^{1 *(D)}$, Fatma ŞAHİNDOKUYUCU KOCASARI ${ }^{2}$ (id}

\author{
${ }^{1}$ Mehmet Akif Ersoy University, Faculty of Arts and Sciences, Department of Chemistry, Burdur, Turkey \\ ${ }^{2}$ Mehmet Akif Ersoy University, Faculty of Veterinary Medicine, Department of Pharmacology and Toxicology, \\ Burdur, Turkey
}

\begin{abstract}
Ortho-phenylphenol (OPP) and sodium ortho-phenylphenate (SOPP) salt have been used world-wide for decades as fungicides and disinfectants. OPP is generally used as a hospital and household disinfectant, whereas SOPP is used as a fungicide in post-harvest treatment of citrus fruits and vegetables for the prevention of mold. Due to widespread use including many consumer applications, the fate of OPP in the mammalian organism has been the subject of numerous investigations over many years. The aim of this review is to give information about OPP and SOPP including metabolism, general toxicity, carcinogenicity and genotoxicity.
\end{abstract}

Keywords: Ortho-Phenylphenol, Sodium ortho-Phenylphenate, Toxicity.

Öz: Orto-fenilfenol (OPP) ve sodyum orto-fenilfenat (SOPP) yıllardır dünya çapında fungisit ve dezenfektan olarak kullanılmaktadır. OPP genellikle hastane ve ev dezenfektanı olarak kullanılırken, SOPP küf oluşumunun önlenmesi için narenciye ve sebzelerin hasat sonrası korunmasını sağlayan bir fungisit olarak kullanılır. Birçok tüketici uygulaması da dahil olmak üzere yaygın kullanım nedeniyle, OPP'nin memeli organizmasındaki kaderi uzun yıllar boyunca çok sayıda araştırmanın konusu olmuştur. Bu derlemede, OPP ve SOPP'nin metabolizma, genel toksisite, karsinojenite ve genotoksisitesi hakkında bilgi verilmesi amaçlanmıştır.

\begin{tabular}{lc}
\hline \multicolumn{2}{l}{ Anahtar Kelimeler: Orto-Fenilfenol, Sodyum Orto-Fenilfenat, Toksisite. } \\
\hline *Corresponding author : Selinay Başak ERDEMLI & e-mail : sberdemli@mehmetakif.edu.tr \\
KÖSE & \\
Geliş tarihi / Received : 09.03.2020 & Kabul tarihi / Accepted: 17.04 .2020 \\
\hline
\end{tabular}

\section{Introduction}

Ortho-phenylphenol (OPP) and its sodium salt, sodium ortho-phenylphenate (SOPP) are phenolic substances which have wide range of uses (Figure 1). These compounds are used as antibacterial and disinfectant agents and fungicides in a variety of different agricultural, industrial and domestic use (Lambert and Eastmond, 1994; WHO, 2003; Balakrishan and Eastmond, 2006). The main use of OPP and SOPP is the preservation of stored fruits especially citrus. They are also used for disinfection of materials used in storage and applied as a fungistatic wax for the destruction of pathogens on the surface of fruits and vegetables.
They can protect the packaged fruits against green mold, blue mold, and sour rot diseases caused by various plant pathogens such as Penicillium italicum, Diplodia natalenis, Penicillium digitatum and Botrytis cinerea (Lyr, 1995; Appel, 2000). OPP and SOPP are used as disinfectant in hospitals, veterinary clinics, poultry farms, cattle enterprises, home and various workplaces (Grossman, 1995; WHO, 2003; Balakrishan and Eastmond, 2006). These substances are very effective disinfection agents especially in stubborn nosocomial infections caused by Pseudomonas aeruginosa and Staphylococcus aureus (Jang et al., 2008; Nde et al., 2008). They are 
also used as biocides to provide control of microbial degradation in fibrous or polymeric materials such as leather, rubber, paper and textile products (Appel, 2000).
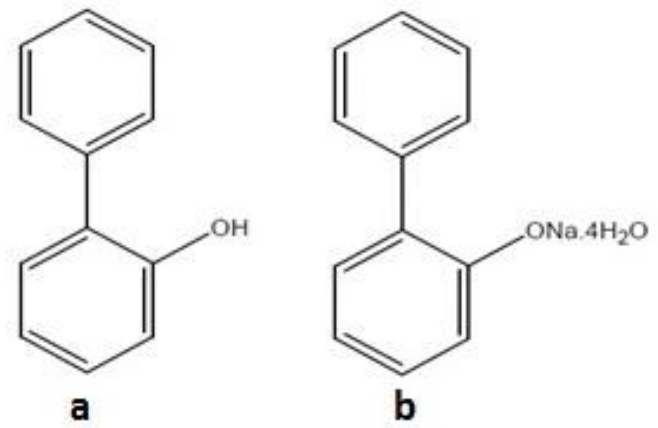

Figure 1. Chemical structures of OPP (a) and SOPP (b) (DPR, 2007).

Due to their widespread usage, living organisms are exposed to OPP and SOPP from many different sources (Kwok and Silva, 2013). Despite these potentially toxic effects, OPP and SOPP are used in applications that come into contact with both humans and animals. The aim of this review is to give information about metabolism, acute and chronic toxicity, carcinogenicity and genotoxicity of OPP and SOPP.

\section{Toxicokinetics}

Bioavailability of OPP and SOPP in rats and mice after oral administration is very high and their elimination via renal system is dose-independently fast (DPR, 2007). OPP and SOPP are metabolized by cytochrome P450 monooxygenase enzyme system in liver. Both compounds are metabolized to phenyl-hydroquinone (PHQ) and phenylbenzoquinone (PBQ) by oxidation reactions and then conjugate and form OPP-S, OPP-G and PHQ-G conjugates by sulfation or glucuronidation. Metabolites of OPP and SOPP undergo reaction with glucuronic acid (GA) or sulfate (S) and excreted in urine (Bomhard et al., 2002; Brusick, 2005). As a result of the conjugation reactions of OPP, biologically inactive metabolites are formed, and as a result of oxidation reactions, active metabolites (PHQ and PBQ) are formed
(Bomhard et al., 2002; Kwok and Silva, 2013). PHQ is a major metabolite formed from OPP and SOPP and it is converted to the corresponding PBQ via reactive phenyl-semiquinone (PSQ) (Nakagawa and Tayama, 1996). PBQ is converted either enzymatically or non-enzymatically. This convertion is occured by the cytochrome P450 monooxygenase enzyme system and prostaglandin $\mathrm{H}$-synthase-mediated oxidation or by $\mathrm{pH}$ dependent autoxidation of PHQ (Kwok and Eastmont, 1997; Balakrishnan and Eastmond, 2006).

In animal studies performed on mainly rats and mice, it was determined that OPP and its main metabolite, PHQ were excreted in low doses as sulfate conjugates (OPP-S and PHQ-S), and in high doses, OPP and PHQ were excreted as GA conjugates (OPP-GA, PHQ-GA) (Ernst，1965; Bajaj et al., 1976; Ushiyama et al., 1982; Nakao et al., 1983; Ushiyama et al., 1983; Christenson et al., 1996). The toxicities of the main molecule and metabolites in vitro and in vivo are as PBQ > PHQ $>$ OPP/SOPP relatively (Brusick, 2005). It has been reported that the PBQ metabolite is responsible for the damage to the urinary bladder epithelium and hyperplasia (St John et al., 2001; Nde et al., 2008). It has been stated that PHQ is formed at high $\mathrm{pH}$ and when it turns into PBQ by oxidation, it causes an increase in the incidence of bladder lesions. Administration of OPP with sodium bicarbonate makes urine alkaline and this resulted in increased carcinogenicity (Fujii et al., 1987; Fukushima et al., 1989; St John et al., 2001). In addition, it has been emphasized that the damage on the bladder is higher due to the higher and faster biotransformation of OPP in male rats (Nakao et al., 1983; Ushiyama et al., 1983).

\section{Mechanism of Action}

Free radicals are constantly formed as a result of enzymatic and non-enzymatic (between oxygen and organic molecules) reactions in cells. Enzymatic reactions can take place during cellular respiration, with phagocytosis, prostaglandin synthesis and the microsomal enzyme system. Free 
radicals are important compounds in regulating processes involving functions such as maintaining cell homeostasis, signal transduction, gene expression and activation of receptors. However, these free radicals and other ROS can occur in large quantities due to normal basic metabolic processes in the living body or exposure to various xenobiotics (Hussain et al., 2016).

The toxicity caused by oxidative damage has been attributed to the higly reactive hydroxl radical, which can be formed by meta ion-catalysed reaction between super oxide anions and hydrogen peroxide (Brusick, 2005). Many toxic xenobiotics such as OPP, which enter the organism, are activated by cytochrome p450 monooxygenase system to produce toxic intermediates and these products bind irreversibly to cellular macromolecules and cause tissue injuries (Nakagawa and Tayama, 1988).

OPP is converted to PHQ and PBQ by microsomal monoxygenase enzyme system. Oxidative stress and cytotoxicity occur due to excessive formation of reactive oxygen species (ROS) as a result of the bilateral reaction between PBQ and the semiquinone radical. This reaction is catalyzed by cytochrome reductase with an electron reduction. By-products of the reaction that forms semiquinone include super oxide anions, hydroxyl radicals and hydrogen peroxide (Brusick, 2005). In various cellular components, PBQ and PHQ are extremely reactive intermediates which can react with cellular nucleophilic centers in biological components (Nakagawa and Tayama, 1996). These reactive metabolites have the potential to inhibit sulfidedependent enzymes. They first consume intercellular glutathione (GSH) stores, and then interact with $\mathrm{SH}$-containing structures in cells and tissues. They also change the effectiveness of catalase, superoxide dismutase and other intracellular antioxidant enzymes. Quinones can also binds to proteins, nucleic acids or other macromolecules and cause damage (Nakagawa and Tayama, 1988; Brusick, 2005; Li et al., 2012).
OPP is thought to cause disorders in endocrine systems and this is the basis of genotoxic and cytotoxic effects. Endocrine disrupting activity of OPP was investigated with in vitro studies on estrogen receptor binding, estrogen-induced cell proliferation, and estrogen receptor transcription activity. There are also studies that OPP and its metabolites have an inhibitory effect on prostaglandin metabolism. Prostaglandin inhibitors have been reported to cause anomalies (increased resorption and cleft lip) in laboratory animals (Bomhard et al., 2002; Kwok and Silva, 2013).

\section{Toxicity}

There seems to be no significant difference between animal species in terms of sensitivity to OPP and SOPP (Bomhard et al., 2002). OPP and SOPP belong to the third category of oral toxicants, but SOPP has approximately 3 times more acute toxicity than OPP (DPR, 2007).

In terms of acute and chronic toxicity, mutagenicity, teratogenicity and cytotoxicity, the effects of OPP and SOPP have been extensively investigated in vitro and in vivo studies (Higara and Fujii, 1981; Ushiyama et al., 1982; Honma et al., 1983; Ushiyama et al., 1983; Higara and Fujii, 1984; Fujii and Higara, 1985; Nakagawa and Tayama, 1988).

\subsection{Acute Toxicity}

\subsubsection{Systemic Toxicity}

LD50/LC50 values of OPP and SOPP in animal species are given in Table 1-2. When OPP and SOPP are taken orally, the LD50 is $924-2700$ $\mathrm{mg} / \mathrm{kg}$. In rats, decrease in respiratory rate, decrease in body temperature, decrease in motor reflexes, coordination disorder, wheezing, cough, increase in urine, depression, exophthalmos, increase in tear secretion, abdominal distension and in mice, clinical signs such as decreased movement, gait disturbance, decreased respiratory rate and depigmentation of hairs were reported (Bomhard et al., 2002; DPR, 2007). 
Nakagawa ve Tayama (1988) gave single dose 700 or $1400 \mathrm{mg} / \mathrm{kg}$ b.w OPP orally to F344 rats and they investigated the toxic effects on liver and kidney. Serum transaminase activity and acute hepatocellular necrosis were observed in the group that receiving $1400 \mathrm{mg} / \mathrm{kg}$ dose of OPP. In groups given 700 and $1400 \mathrm{mg} / \mathrm{kg}$ b.w OPP, glutathione levels decreased rapidly depending on the dose after 6 hours. The researchers then treated the rats with PHQ and PBQ (the metabolites of OPP) at 700 and $1400 \mathrm{mg} / \mathrm{kg}$ b.w. doses. They observed that $75 \%$ of the animals in the group given PBQ at $1400 \mathrm{mg} / \mathrm{kg}$ b.w dose died at the end of 24 hours. It has been stated that serum transaminase activities increase significantly at the doses $1400 \mathrm{mg} / \mathrm{kg}$ b.w PHQ and $700 \mathrm{mg} / \mathrm{kg}$ b.w PBQ. Hepatocellular necrosis were seen in the group which $700 \mathrm{mg} / \mathrm{kg}$ b.w of PBQ applied and it is also have been reported that serum urea nitrogen levels increase in this group of rats. They stated that tubular enlargement in kidneys and renal papillary necrosis were milder in groups receiving $700 \mathrm{mg} / \mathrm{kg}$ b.w PBQ. At the higher doses of OPP and its metabolites (PBQ and PHQ), it has been reported that target organs are the liver and kidney. They found that PBQ has a much more toxic effect on liver and kidney than PHQ.

Table 1. Acute toxicity of OPP in rat and mice (LD50/LC50 values) (Bomhard et al., 2002).

\begin{tabular}{lllll}
\hline Species & Route & Sex & LD50/LC50 & References \\
\hline Rat & Oral & Male & $2850 \mathrm{mg} / \mathrm{kg} \mathrm{b.w}$ & Hasegawa et al.(1989) \\
& & Female & $3600 \mathrm{mg} / \mathrm{kg} \mathrm{b.w}$ & Hasegawa et al. (1989) \\
& & Male/Female & $2733 \mathrm{mg} / \mathrm{kg} \mathrm{b.w}$ & Gilbert and Crissman (1994) \\
& Dermal & Male/Female & $>2000 \mathrm{mg} / \mathrm{kg} \mathrm{b.w}$ & Bomhard (1991) \\
& Inhalation & Male $/$ Female & $>36 \mathrm{mg} / \mathrm{m}^{3}$ & Landry et al. (1992) \\
& (4h) & & (as vapour) & \\
& Oral & Male & $3499 \mathrm{mg} / \mathrm{kg} \mathrm{b.w}$ & Tayama et al. (1983) \\
& & Female & $3152 \mathrm{mg} / \mathrm{kg}$ b.w & Tayama et al. (1983) \\
\hline
\end{tabular}

Table 2. Acute toxicity of SOPP in rat and mice (LD50/LC50 values) (Bomhard et al., 2002).

\begin{tabular}{lllll}
\hline Species & Route & Sex & LD50/LC50 & References \\
\hline Rat & Oral & Male & $1650 \mathrm{mg} / \mathrm{kg} \mathrm{b.w}$ & Taniguchi et al. (1981) \\
& & Female & $1550 \mathrm{mg} / \mathrm{kg} \mathrm{b.w}$ & Taniguchi et al. (1981) \\
& & Male $/$ Female & $1096 \mathrm{mg} / \mathrm{kg} \mathrm{b.w}$ & Tayama et al. (1979) \\
& Inhalation & Male & $>1331 \mathrm{mg} / \mathrm{m}^{3}$ & Mihail and Kimmerle (1977) \\
& $(1 \mathrm{~h})$ & & $($ aerosol dissolved in & \\
& & & water $)$ & \\
Mice & Oral & Male & $1018 \mathrm{mg} / \mathrm{kg} \mathrm{b.w}$ & Ogata et al. (1979) \\
& & Female & $683 \mathrm{mg} / \mathrm{kg} \mathrm{b.w}$ & Ogata et al. (1979) \\
\hline
\end{tabular}

\subsubsection{Skin İritation}

There are available data on skin irritation caused by OPP and SOPP in rabbits (Norris, 1971a; Schreiber, 1981; Thyssen, 1982; Suberg, 1983;
Maertins, 1988; Gilbert, 1994). Skin irritation potential tests were positive for both substances (Table 3). While OPP is a strong irritant on the skin, sodium salt has a corrosive effect (Bomhard et al., 2002). 


\subsubsection{Eye İrritation}

There are studies on rabbits about the toxic effects of OPP and SOPP on the eye (Norris, 1971a,b; Schreiber, 1981; Pauluhn, 1983; Maertins, 1988). In these studies, permanent opacity in cornea, iritis, conjunctivitis, redness, chemosis, necrosis and exudates were clinically observed. Studies on rabbits have shown that SOPP and OPP are in category I among the toxic substances that affect the eyes (DPR, 2007). While OPP is moderately irritant to the eyes, SOPP has a corrosive effect (Table 4) (Bomhard et al., 2002).

Table 3. Skin irritation of OPP and SOPP in rabbit (Bomhard et al., 2002).

\begin{tabular}{lccll}
\hline Substance & $\begin{array}{c}\text { Exposure } \\
\text { duration }\end{array}$ & $\begin{array}{c}\text { Obsevation } \\
\text { periyod (day) }\end{array}$ & Result & References \\
\hline OPP & $4 \mathrm{~h}$ & 8 & Mildly irritant & Norris (1971a) \\
& $4 \mathrm{~h}$ & 3 & Strongly irritant & Thyssen (1982) \\
& $30 \mathrm{~min}$ & 10 & Mildly irritant & Suberg (1983) \\
SOPP & $4 \mathrm{~h}$ & 15 & Strongly irritant & Gilbert (1994) \\
& $4 \mathrm{~h}$ & 7 & Corrosive & Maertins (1988) \\
& $24 \mathrm{~h}$ & 7 & Strongly irritant & Pauluhn (1983) \\
\hline
\end{tabular}

Table 4. Eye irritation of OPP and SOPP in rabbit (Bomhard et al., 2002).

\begin{tabular}{lccll}
\hline Substance & $\begin{array}{c}\text { Amount } \\
\text { (mg) }\end{array}$ & $\begin{array}{c}\text { Post-exposure period } \\
\text { (day) }\end{array}$ & Result & References \\
\hline OPP & 100 & 7 & Moderately irritant & Norris (1971b) \\
OPP & 100 & 8 & Moderately irritant & Schreiber (1981) \\
SOPP & 100 & 7 & Corrosive & Pauluhn (1983) \\
& 40 & 7 & Corrosive & Maertins (1988) \\
\hline
\end{tabular}

\subsection{Subacute, Subchronic and Chronic Toxicity}

There are several studies on rats, mice and dogs about the subchronic toxicity of OPP and SOPP. OPP mainly affects the kidney and urinary bladder in rats. In male rats, increase in kidney weight, decrease in kidney function, nephritis, papillary necrosis, pelvis/papilla hyperplasia and increase in the kidney tubular cells are the some of alterations. OPP is thought to affect the kidney (with a decrease in urinary $\mathrm{pH}$ and the formation of nephritis) in females, but limited data are available on this subject. SOPP is also affects kidney, urinary bladder and liver. SOPP has several effects on kidneys such as increased organ weight and pyelonephritis in both sexes. There are studies about the effects of OPP and SOPP on chronic toxicity and oncogenicity in rats, mice and dogs, and the triggering effects of SOPP in the urinary tract in guinea pigs and hamsters. The toxicities of OPP and SOPP vary according to gender and species. It has been reported that in rats OPP has an effect on the optic nerves, spleen and heart, primarily in the kidney and urinary tract (Higara and Fujii, 1981; Ushiyama et al., 1982; Honma et al., 1983; Ushiyama et al., 1983; Higara and Fujii, 1984; Fujii and Higara, 1985).

Higara and Fujii (1981) administered SOPP at the rates of $\% 0,0.125,0.25,0.5,1,2$ and 4 with feed to male and female rats for 13 weeks. At the end of this period, they reported that a urinary bladder tumor developed in 1 of those given 1\% SOPP, 9 of those given $2 \%$ SOPP and 1 of those given $4 \%$ SOPP in male rats and 2 of those given $4 \%$ SOPP 
in female rats. In the 91st week, researchers found that papillary tumors in the kidney and urinary bladder developed in 1 of the rats given $0.5 \%$ SOPP, 7 of the rats given 1\% SOPP, 20 of the rats given $2 \%$ SOPP and 17 of the rats given $4 \%$ SOPP.

Higara and Fujii (1984) applied OPP at the rates of $0.156,0.313,0.625,1.25$ and $2.5 \%$ with feed to male and female rats for 13 weeks. At the end of this period, the authors found that $50 \%$ of the animals had urinary bladder tumors in the group receiving 1.25\% OPP. At the end of the 91st week, the researchers found that urinary bladder tumors in $96 \%$ of the rats in $1.25 \%$ OPP group and $17 \%$ of the rats in $2.5 \%$ OPP group were developed.

In another study, 0, 0.25, 0.5, 1 and 2\% OPP was given to the group of 15 rats for 12 weeks. In the 4 th, 8 th and 12 th weeks, urinary bladder of 5 rats of each group were examined under light and electron microscope and no change was observed in the group receiving 1\% OPP. From 4th week, in the group receiving $2 \% \mathrm{OPP}$, damage in the microvilli in the lumen of epithelial cells was detected by Scanning Electron Microscope (TEM) images (Oehme, 1971).

SOPP was given to 20 male F344 rats by adding feed at $0,0.625,1.25$ and $2.5 \%$ concentration for 13 weeks, and in groups fed with 1.25 and $2.5 \%$ SOPP, decreases in weight were reported. It was stated that there was no change in biochemical parameters in plasma samples. A decrease in the number of red blood cells, the amount of hemoglobin and the weight of the bladder was reported in the group receiving $2.5 \%$ SOPP. In groups given 1.25 and $2.5 \%$ OPP, it was reported that the number of rats whose urine $\mathrm{pH}$ was acidic increased and urine protein levels decreased in the $2.5 \%$ OPP group (Nakamura et al., 1981).

It was reported that SOPP was given to the group consisting of $50 \mathrm{~F} 344$ male rats by adding to feed at $0.25,0.5,1$ and $2 \%$ concentration for 36 weeks and samples from 10 rats in each group were examined with light and scanning electron microscopes at 4, 8, 12, 24 and 36 weeks. Slight hyperplasia in the urinary bladder was reported in the group given $2 \%$ SOPP, and $40 \%$ of the rats examined at 36th week had papillary and nodular (PN) hyperplasia. It was stated that high-grade epithelial surface damages observed in $1 \%$ and $2 \%$ SOPP groups were detected by scanning electron microscope (Oehme, 1971).

Honma et al. (1983) fed 40 male F344 rats with feed containing $2 \%$ SOPP for 50 weeks and at the end of the study researcher found that $86 \%$ of rats had PN hyperplasia, 53\% of them had papillomas and $39 \%$ of them had transitional cell carcinoma. It was reported that in 3 rats papilloma in the pelvis renalis and in 9 rats PN hyperplasia were detected, and there were no tumors in the control group.

Hasegawa et al. (1990) applied 2\% SOPP to 30 male F344 rats for 48 weeks, and at the 4 th, 6th, 12th, 24th, 36th and 48th weeks, they examined the urinary bladders of groups of 5 rats with light and scanning electron microscope. They reported that there was a pause in body weight increase throughout the study and simple epithelial hyperplasia and pleomorphic microvilli occurred in all groups. At 36 and 48 weeks, PN hyperplasia were observed in all groups of rats and at 12 th and 48th weeks, they stated that $\mathrm{pH}$ of the urine increased and crystaline structures were seen in the urine.

OPP and SOPP were given to 30 male F344 rats by adding feed at $2 \%$ doses for 90 days and blood, urine, liver, kidney and urinary bladder samples were taken on the days 3, 7, 14, 30, 65 and 90. It was stated that feed consumption and body weights decreased in both groups, especially in the group which OPP was given. In addition, an increase in mortality was reported in the group receiving OPP between days 7 and 14. In the group which SOPP was given, decrease in feed intake and body weights returned to the normal after two weeks, while this situation continued in animals receiving OPP. In animals receiving 2\% $\mathrm{OPP}$, a decrease in urinary density, blood in urine and cysts in kidney were reported on the 65th and 
90th days. It was also stated that urinary bladder tumors were not observed in any of the animals (Okuda, 1986).

OPP was given to $70 \mathrm{~F} 344$ rats of both sexes at doses of $0,0.08,0.4$ and $0.8 \%$ to males and $0,0.08$, 0.4 and $1 \%$ to females. At the end of the 1 -year period, 20 animals were euthanized for further research. It was stated that average body weight decreased at medium and high doses in both sexes, while there was no change in feed consumption and there was a small increase in mortality in male rats. In groups receiving $0.4 \%$ and more OPP, changes in urine color were observed. At high doses in male rats, it has been reported that urine samples contain blood. In groups receiving moderate and high doses of OPP, involuntary urination during death and masses in urinary bladder were detected at necropsy. At the end of 1 year, hyperplasia in the bladder in all 20 of the animals, transitional cell carcinoma in 3 of them and papilloma in 6 of them were reported in the group receiving $0.8 \%$ OPP. At high doses, the rate of stone formation in kidneys increased in males, while cystic tubular enlargement and chronic ischemia in kidney were detected in females. Simple hyperplasia ( $84 \%$ in males, $12 \%$ in females) and PN hyperplasia (86\% in males, $2 \%$ in females) have been reported in the urinary bladder at high doses (Ushiyama et al., 1982, 1983).

Fujii and Hiraga (1985) administered SOPP to 50 F344 rats. Males at rates of $0 \%, 0.7 \%$ and $2 \%$ for 106 weeks, and females at rates of $0,0.5$ and $1 \%$ for 104 weeks (2 weeks basal diet) were received SOPP. They found that body weight was lower than other groups in males given $2 \%$ SOPP and females given 1\% SOPP. They observed that in males given $2 \%$ SOPP, blood was observed in the urine from the 40th week and continued to increase until the end of the study. At the end of the 106th week, 47 of 50 males receiving $2 \%$ SOPP developed a bladder tumor. They found that carcinomas metastasize to the lung in 15\% of males given 2\% SOPP. Increased interstitial nephritis and pyleonefritis were observed in females receiving $1 \%$ SOPP.
OPP was given to $20 \mathrm{~B} 6 \mathrm{C} 3 \mathrm{~F} 1$ male mice (4 groups, 13 in each) for 52 weeks by feed at the rates of $0,6500,13000$ and $26000 \mathrm{ppm}$. In the $13000 \mathrm{ppm}$ OPP group, death was observed at 40 weeks. In 13000 and 26000 ppm OPP groups, decreases in body weight and feed consumption were observed. It has been determined that OPP has an effect on liver, kidney and spleen in mice. Increase in organ weight in both sexes of the liver, increase in the formation of nonneoplastic (focal necrosis, anisonucleosis, liver cells and pigment residues in phagocytes), preneoplastic (eosinophilic cell foci) and neoplastic (adenoma, hepatoblastoma and carcinoma) lesions, atrophy in the spleen were observed (DPR, 2007). On the other hand, in other studies on OPP and/or SOPP in mice, no histopathological findings were found in the urinary bladder (Savides and Oehme, 1980; Fukushima et al., 1982; Selim, 1996) and they did not cause any toxic effects in urine and changes in blood analysis (Savides and Oehme, 1980; Hasegawa et al., 1990; Selim, 1996).

OPP was given to F344 rats from both sex for 21 days, 5 days a week, once a day at 0,100, 500 and $1000 \mathrm{mg} / \mathrm{kg}$ b.w. It was reported that in group of rats which were given 500 and $1000 \mathrm{mg} / \mathrm{kg}$ b.w OPP, skin rashes were detected at the application site and no histopathological changes were observed in any group (Wick and Gschwend, 1998).

OPP (dissolved in acetone) was applied to $50 \mathrm{CD}$ 1 mice 3 times a week for 102 weeks and no effect was detected on the skin. Likewise, SOPP (dissolved in acetone) was applied to 20 female CD-1 mice for 47 weeks twice a week and it was stated that no effect was observed on the skin (Shibata et al., 1985).

\subsection{Genotoxicity}

Previously some studies reported that OPP and its metabolites showed weak genotoxic effects (Reitz et al., 1983, 1984). However, there are also in vivo and in vitro studies reporting that OPP, SOPP, PBQ and PHQ may have genotoxic effects (Roy, 1990; Pathak and Roy, 1993; Nakagawa and 
Tayama, 1996). The reactive metabolites have potential for causing damage to biomacromolecules (proteins, peptides and DNA). Reactive PBQ and PHQ metabolites have been shown to bind covalently to both in vivo and in vitro intracellular biomacromolecules and nucleophilic centers (Pathak and Roy, 1993; Nakagawa and Tayama, 1996). Roy (1990) has demonstrated that P450 microsomal cytochromes catalyze the redox cycle of OPP. Morimoto et al. (1989) showed indirect evidence that reactive metabolites of OPP may cause DNA damage.

Results of Salmonella typhimurium or Escherichia coli tests indicated that OPP (Kojima and Hiraga, 1978; Kojima et al., 1983) and SOPP (Kojima and Hiraga, 1978) did not cause to point mutations in bacteria. However some investigators reported that OPP caused point mutations in mammalian cells (mouse lymphoma, human RSa cells) in vitro (Suzuki et al., 1985; NTP, 1986). On the other hand PHQ (Lambert, 1992) and PBQ (Reid et al., 1998) did not induce point mutations in the mammalian cells (PHQ-Chinese hamster V 79 cells, PBQ-AHH-1 human lymphosblastoid cells).

Results of chromosomal damage (i.e., clastogenicity, endoreduplication and aneugenicity) studies indicated that OPP and SOPP caused damages in chromosomes of mammalian cells in vitro (Kawachi et al., 1981; Tayama et al., 1989; Tayama and Nakagawa, 1991) and in vivo (Tadi-Uppala et al., 1996; Balaskrishnan et al., 2002; Balakrishnan and Easmond, 2006). Tadi-Uppala et al. (1996) administered rats to OPP, SOPP, $\mathrm{NaCl}$ or OPP $+\mathrm{NaCl}$ in addition to their diet. They reported that micronucleus increases were observed in the bladder cells of animals given OPP and SOPP. Balakrishnan et al. (2002) examined the genotoxic effects of OPP and SOPP with their studies on the rat urinary bladder. It has been stated that the administration of OPP and SOPP together with the diet for 2 years caused tumor induction in the bladder and increased cell proliferation and micronucleus formation from the 2nd week. In addition, Balakrishnan and Eastmond (2006) reported that chromosal breakage and base losses may be the cause of increases in micronucleus formation in the urinary bladder.

OPP irreversibly bind to DNA with covalent bonds (Ushiyama et al., 1992) and rat liver in vitro (Pathak and Roy, 1992). Pathak and Roy (1992) investigated the covalent binding of PBQ to rat liver DNA using the ${ }^{32} \mathrm{P}$-postlabeling technique. Four major and several minor adducts have been revealed. As a result of the chemical reaction between PBQ and deoxyguanosine 3-phosphate oligonucleotides (dGMP), 4 major substances were formed. Modifications resulting from covalent bonds between DNA and the reactive metabolite of OPP precisely determined the presence of in vitro genotoxic effects of OPP.

Ushiyama et al. (1992) investigated the formation of DNA adduct caused by OPP. In the presence or absence of rat liver microsomes, they investigated the covalent binding of OPP to calf thymus DNA. It is stated that DNA binding did not occur as a result of incubation without microsomes or when the microsomes are denatured with heat. As a result, it has been suggested that biotransformation of OPP to active metabolites is a prerequisite for DNA binding. Inoue et al. (1990) found that PHQ causes oxidative DNA damage in the presence of copper II $\left(\mathrm{Cu}^{2+}\right)$.

Murata et al. (1999) reported that PHQ and PBQ can cause oxidative DNA damage in the peripheral blood promyeloblast cells (HL60) via $\mathrm{H}_{2} \mathrm{O}_{2}$ production resulting in mutation and carcinogenesis due to this damage. As a result of the genotoxicity studies, it has been stated that OPP, SOPP and its metabolites may cause gene mutation, chromosomal and DNA damage.

\section{Conclusion}

OPP and SOPP produce toxic effects that are widespread in the phenolic class. Compared with other phenol derivatives, OPP shows a highly lipophilic and electrophilic structure. These physicochemical properties are extremely 
important in terms of transport from membranes and their interaction with target macromolecules (eg DNA, protein, lipids). After OPP and SOPP enter the body, they turn into reactive metabolites. Both these active metabolites (PHQ and PBQ) and the free oxygen radicals produced by the reactions are thought to be accountable for the toxic effects of OPP and SOPP.

In the light of the studies, it has been indicated that rather than acute exposure these substances are subcronically and chronically exposed and cause carcinogenic effects. It has been stated that OPP and SOPP reveal toxic effects on the kidney and liver, especially the urinary tract. In addition, it has been highlighted by studies that genotoxic effects are observed as a result of covalent binding of metabolites to DNA.

\section{References}

Appel, K.E., 2000. The carcinogenicity of the biocide ortho-phenylphenol. Archives of Toxicology 74, 61-71.

Bajaj, K.L., Miller, I.R., Bhatia, I.S., 1976. Metabolism of 2-hydroxybiphenyl \& 4hydroxybiphenyl in albino mice. Indian Journal of Experimental Biology 14, 329-331.

Balakrishan, S., Eastmond, D.A., 2006. Micronuclei and cell proliferation as early biological markers of orho-phenylphenol-induced changes in the bladder of male F344 rats. Food and Chemical Toxicology 44, 1340-1347.

Balakrishnan, S., Uppala, P.T., Rupa, D.S., Hasegawa, L., Eastmond, D.A., 2002. Detection of micronuclei, cell proliferation and hyperploidy in bladder epithelial cells of rats treated with ophenylphenol. Mutagenesis 17, 89-93.

Bomhard, E., 1991. Preventol O extra (Schuppen) Untersuchungenzur akuten dermalen Toxizitaet an maennlichen und weiblichen Wistar-Ratten. Bayer AG, Report No.19831.

Bomhard, E.M., Brendler-Schwaab, S.Y., Freyberger, A., Herbold, B.A., Leser, K.H., Richter, M., 2002. o-Phenylphenol and its sodium and potassium salts: a toxicological assessment. Critical Reviews in Toxicology 32, 551-625.

Brusick, D., 2005. Analysis of genotoxicity and the carcinogenic mode of action for ortho-phenylphenol.
Environmental and Molecular Mutagenesis 45, 460481.

Christenson, W.R., Whale, B.S., Bartels, M.J., Cohen, S.M., 1996. Technical grade orthophenylphenol: A ${ }^{32}$ P-postlabeling study to examine the potential for the formation of DNA adducts in the urinary bladder of male rats. The Dow Chemical Inc. Laboratory Project I.D. 94-972-AV.

DPR, 2007. Ortho-Phenylphenol and sodium orthophenylphenate Risk Characterization Document Dietary Exposure. California Environmental Protection Agency, ABD.

Ernst, W., 1965. Umwandlung und Ausscheidung von 2-hydroxydiphenyl bei der Ratte. Arzneimittelforschung 15, 632-636.

Fujii, T., Hiraga, K., 1985. Carcinogenicitytesting of sodium ortho-phenylphenate in F344 rats. Journal of Saitama Medical School 12, 277-287.

Fujii, T., Nakamura, K., Hiraga, K., 1987. Effects of $\mathrm{pH}$ on the carcinogenicity of o-phenylphenol and sodium ophenylphenate in the rat urinary bladder. Food and Chemical Toxicology 25, 359-362.

Fukushima, S., Hasegawa, R., Kurata, Y., Okuda, M., Hatano, A., Ito, N., 1982. Histopathological and ultrastructural analysis of urinary bladder lesions in animals induced by sodium o-phenylphenate. Proceedings of Japan Cancer Association (41th Annual Meeting, 314, (abstract).

Fukushima, S., Inoue, T., Uwagawa, S., Shibata, M.A., Ito, N., 1989. Cocarcinogenic effects of $\mathrm{NaHCO}_{3}$ on ophenylphenol-induced rat bladder carcinogenesis. Carcinogenesis 10, 1635-1640.

Gilbert, K.S., 1994. Dowicidetm1 antimicrobial; primary dermal irritation study in New Zealand White rabbits. Dow Chemical, Report No. K-001024-057b.

Gilbert, K.S., Crissman, J.W., 1994. Dowicidetm1 antimicrobial; acute oral toxicity study in Fischer 344 rats. Dow Chemical, Report No. K-001024-057a.

Grossman, J., 1995. What's hiding under the sink: dangers of household pesticides. Environmental Health Perspectives 103, 550-554.

Hasegawa, R., Nakaji, Y., Kurokawa, Y., Tobe, M., 1989. Acute toxicity tests on 113 environmental chemicals. The science reports of the research institutes, Tohoku University, 36, 1-4. 
Hasegawa, R., Takahashi, S., Asamoto, M., Shirai, T., Fukushima, S., 1990. Species differences in sodium o-phenylphenate induction of urinary bladder lesions. Cancer Letters 50, 87-91.

Hiraga, K., Fujii, T., 1981. Induction of tumors of the urinary system in F344 rats by dietary administration of sodium o-phenylphenate. Food and Cosmetics Toxicology 19, 303-310.

Hiraga, K., Fujii, T., 1984. Induction of tumors of the urinary bladder in F344 rats by dietary administration of o-phenylphenol. Food and Chemical Toxicology 22, 865-870.

Honma, Y., Kakizoe, T., Komatsu, H., Niijima, T., Sugimura, T., 1983. Increased agglutinability of bladder epithelial cells by concanavalin A in rats fed several biphenyl derivatives. Journal of Cancer Research and Clinical Oncology 106, 176-178.

Hussain, T., Tan, B., Yin, Y., Blachier, F., Tossou, M.C., Rahu N., 2016. Oxidative stress and inflammation: What polyphenols can do for us? Oxid Med Cell Longevity, Article ID 7432797. doi: 10.1155/2016/7432797.

Inoue, S., Yamamoto, K., Kawanishi, S., 1990. DNA damage induced by metabolites of o phenylphenol in the presence of copper(II) ions. Chemical Research in Toxicology 3, 144-149.

Jang, H., Nde, C., Toghrol, F., Bentley, W.E., 2008. Microarray analysis of toxicogenic effects of orthophenylphenol in Staphylococcus aureus. BMC Genomics 9, 411.

Kawachi, T., Yahagi, T., Kada, T., Tazima, Y., Ishidate, M., Sasaki, M., Sugiyama, T., 1981. Cooperative programme on short-term assays for carcinogenicity in Japan. IARC Scientific Publications 27, 323-330.

Kojima, A., Fujita, H., Hiraga, K., 1983. Mutagenicity of ophenylphenol (OPP) in the microbial system. Annual Report of the Tokyo Metropolitan Research Laboratory of Public Health 34, 319-324.

Kojima, A., Hiraga, K., 1978. Mutagenicity of citrus fungicides in microbial system. Annual Report of the Tokyo Metropolitan Research Laboratory of Public Health 29, 83-85.

Kwok, E.S.C., Eastmond, D.A., 1997. Effects of pH on nonenzymatic oxidation of phenyl-hydroquinone: potential role in urinary bladder carcinogenesis induced by ophenylphenol in Fischer 344 rats. Chemical Research in Toxicology 10, 742-749.
Kwok, E.S.C., Silva, M.H., 2013. Re-evaluation of Developmental and Reproductive Toxicity of OrthoPhenylphenol (OPP) and Sodium OrthoPhenylphenate (SOPP). Cell and Developmental Biology 2(3), 1-12.

Lambert, A.C., 1992. Mechanisms of genotoxicity induced by the ortho-phenylphenol metabolites phenylhydroquinone and phenylbenzoquinone. Master Thesis, Univercity of California Riverside.

Lambert, A.C., Eastmond, D.A., 1994. Genotoxic effects of the o-phenylphenol metabolites phenylhydroquinone and phenylbenzo-quinone in V79 cells. Mutation Research 322, 243-256.

Landry, T.D., Stebbins, K.E., Battjes, J.E., 1992. Orthophenylphenol: acute aerosol inhalation toxicity study in Fischer 344 rats. Dow Chemical, Report No. K-001024-049.

Li J, Yang G, Wang S, Jiang L, Liu X, Geng C, Zhong L, Chen M., 2012. The protective effects of hydroxytyrosol against ortho-phenylphenol-induced DNA damage in HepG2 cells. Toxicology Mechanisms and Methods 22(6), 432-437.

Lyr, H., 1995. Aromatic hydrocarbon fungicides and their mechanism of action. In: Modern selective fungicides. Gustav Fischer, pp 75-98.

Maertins, T., 1988. Preventol ON: Untersuchungen zum Reiz-/Aetzpotential an Haut und Auge (Kaninchen) nach OECD-Richtlinie No. 404 und 405. Bayer AG Report- No. 16951.

Mihail, F., Kimmerle, G., 1977. Preventol O und Preventol ON: Bestimmung der Inhalations-toxizitaet. Bayer AG, Report.

Morimoto, K., Sato, M., Fukuoka, M., Hasegawa, R., Takahashi, T., Tsuchiya, T., Tanaka, A., Takahashi, A., Hayashi, Y., 1989. Correlation between the DNA damage in urinary bladder epithelium and the urinary 2- phenyl-1,4benzoquinone levels from F344 rats fed sodium ophenylphenate in the diet. Carcinogenesis 10, 18231827.

Murata, M., Moriya, K., Inoue, S., Kawanishi, S., 1999. Oxidative damage to cellular and isolated DNA by metabolites of a fungicide ortho-phenylphenol. Carcinogenesis 20(5), 851-7.

Nakagawa, Y., Tayama, K., 1988. Effect of buthionine sulfoximine on ortho-phenylphenolinduced hepato- and nephrotoxic potential in male rats. Archives of Toxicology 62, 452-457. 
Nakagawa, Y., Tayama, S., 1996. Induction of 8 hydroxy-2'-deoxyguanosine in $\mathrm{CHO}-\mathrm{KL}$ cells exposed to phenylhydroquinone, a metabolite of orthophenylphenol. Cancer Letters 101, 227-232.

Nakamura, K., Iguchi, S., Ikeda, T., Hiraga, K., 1981. Subacute toxicity of o-phenylphenol by food administration to male rats. Annual Report of the Tokyo Metropolitan Research Laboratory of Public Health 32, 33-39.

Nakao, T., Ushiyama, K., Kabashima, J., Nagai, F., Nakagawa, A., Ohno, T., Ichikawa, H., Kobayashi, H., Hiraga, K., 1983. The metabolic profile of sodium o-phenylphenate after subchronic oral administration to rats. Food and Chemical Toxicology 21, 325-329.

Nde, C.W., Jang, H.J., Toghrol, F., Bentley, W.E., 2008. Toxicogenomic response of Pseudomonas aeruginosa to ortho-phenylphenol. BMC Genomics 9, 473.

Norris, J.M., 1971a. Product chemistry, acute toxicological organisms data for Dowicide-1 antimicrobial. Dow Chemical Company, DPR Vol. 129-0044.

Norris, J.M., 1971b. Toxicology and residue data on Dowicide A antimicrobial. Dow Chemical Company, DPR Vol. 50438-0007.

NTP, 1986. Technical report on the toxicology and carcinogenesis studies of ortho phenylphenol (CAS No. 90-43-7) alone and with 7,12dimethylbenz(a)anthracene (CAS No. 57-97-6) in Swiss CD-1 mice dermal studies). NIH Publication No. 85-2557, NTP 84-099, US Department of Health and Human Services, NTP TR 301.

Oehme, F.W., 1971. Comparative toxicity of ophenylphenol and an o-phenolphenol containing disinfectant. Toxicology and Applied Pharmacology 19, 412.

Ogata, A., Ando, H., Kubo, Y., Hiraga, K., 1979. Acute oral toxicity of sodium o-phenylphenate (OPP$\mathrm{Na}$ ) in mice. Annual Report of the Tokyo Metropolitan Research Laboratory of Public Health 30, 54-56.

Okuda, M., 1986. Pathological analysis of the carcinogenic effect of sodium o-phenylphenol and ophenylphenol in the urinary bladder of rats and mice. Journal of the Nagoya City University Medical Association 37, 157-184

Pathak, D.N., Roy, D., 1992. Examination of microsomal cytochrome P450-catalyzed in vitro activation of ophenylphenol to DNA binding metabolite(s) by 32P postlabeling technique. Carcinogenesis 13, 1593-1597.

Pathak, D.N., Roy, D., 1993. In vivo genotoxicity of sodium ortho-phenylphenol: phenylbenzoquinone is one of the DNA-binding metabolite(s) of sodium orthophenylphenol. Mutation Research 286, 309-319.

Pauluhn, J., 1983. Preventol ON extra: Untersuchungen auf hautund schleimhautreizende Wirkung. Bayer AG, Report.

Reid TM, DeBord DG, Cheever KL, Savage RE Jr., 1998. Mutagenicity of N-OH-MOCA (4-amino-4'hydroxylamino-bis-3,3'-dichlorodiphenylmethane) and PBQ (2-phenyl-1,4-benzoquinone) in human lymphoblastoid cells. Toxicology Letters 95(3), 205-10.

Reitz, R.H., Fox, T.R., Quast, J.F., Hermann, E.A., Watanabe, P.G., 1983. Molecular mechanisms involved in the toxicity of o-phenylphenol and its sodium salt. Chemico-Biological Interactions 43, 99119.

Reitz, R.H., Fox, T.R., Quast, J.F., Hermann, E.A., Watanabe, P.G., 1984. Biochemical factors involved in the effects of orthophenylphenol (OPP) and sodium orthophenylphenate (SOPP) on the urinary tract of male F44 rats. Toxicology and Applied Pharmacology 73, 345-9.

Roy, D., 1990. Cytochrome P-450 catalyzed redox cycling of orthophenylphenol. Biochemistry International 22, 849-857.

Savides, M.C., Oehme, F.W., 1980. Urinary metabolism of orally administered ortho-phenylphenol in dogs and cats. Toxicology 17, 355-363.

Schreiber, G., 1981. Pruefung von Peventol O extra auf Schleimhautreizwirkung. Fraunhofer-Institut für Toxikologie und Aerosolforschung.

Selim, M., 1996. A single dose open label study to investigate the absorption and excretion of ${ }^{14} \mathrm{C} /{ }^{13} \mathrm{C}$ labeled ortho-phenylphenol formulation after dermal application to healthy volunteers. Pharma Bio-Research Clinics BV, Assen, Netherlands, Report No. P0995002.

Shibata, M.A., Hagiwara, A., Tamano, S., Fukushima, S., Ito, N., 1985. Subchronic toxicity study of sodiumo-phenylphenate in mice. Toxicology Letters 25, 239-246.

St. John, M.K., Arnold, L.L., Cano, M., Johansson, S.L., Cohen, S.M., 2001. Dietary Effects of ortho- 
Phenylphenol and Sodium ortho-Phenylphenate on Rat Urothelium. Toxicological Sciences 59(2), 346-351.

Suberg, H., 1983. Preventol O extra (OPP): Untersuchung auf primaere Reiz-/Aetzwirkung an der Kaninchenhaut. BAYER AG Institut für Toxikologie, Report.

Suzuki, H., Suzuki, N., Sasaki, M., Hiraga, K., 1985. Orthophenylphenol mutagenicity in a human cell strain. Mutation Research 156, 123-127.

Tadi-Uppala., P., Hasegawa, L., Rupa, D.S., Eastmond, D.A., 1996. Detection of micronuclei and cell proliferation in the rat bladder induced by the fungicides o-phenylphenol and sodium ortho phenylphenate. Carcinogenesis 37, 127-128 (abstract).

Taniguchi, Y., Morimoto, J., Okada, K., Imai, S., Tsubura, Y., 1981. Toxicological study of sodium orthophenylphenate (OPP-Na) in rats. II. Acute oral toxicity in Fischer 344 DuCrj rats. Journal of the Nara Medical Association 32, 709-714.

Tayama, K., Iguchi, S., Hiraga, K., 1979. Acute oral toxicity of sodium o-phenylphenol (OPP-Na) in rats. Annual Report of the Tokyo Metropolitan Research Laboratory of Public Health 30, 57-65.

Tayama, K., Iguchi, S., Sasaki, M., Hiraga, K., 1983. Acute oral toxicity of o-phenylphenol (OPP) in mice. Annual Report of the Tokyo Metropolitan Research Laboratory of Public Health 34, 325-328.

Tayama, S., Kamiya, N., Nakagawa, Y., 1989. Genotoxic effects of o-phenylphenol metabolites in CHO-K1 cells. Mutation Research 223, 23-33.
Tayama, S., Nakagawa, Y., 1991. Sulfhydryl compounds inhibit the cyto- and genotoxicity of $\mathrm{O}$ phenylphenol metabolites in CHO-K1 cells. Mutation Research 259, 1-12.

Thyssen, J., 1982. Preventol O extra: Gewerbetoxikologische Untersuchungen. Bayer AG, Report No. 10541.a

Ushiyama, K., Kabashima, J., Nakao, T., 1982. Metabolism of 2-phenylphenol (OPP) in rats: metabolic profile of OPP in rats fed dietary for long period. Annual Report of the Tokyo Metropolitan Research Laboratory of Public Health 33, 455-457.

Ushiyama, K., Kabashima, J., Nakao, T., 1983. Metabolism of o-phenylphenol sodium salt (OPPNa) in rats: dose response of metabolic profile of OPP. Annual Report of the Tokyo Metropolitan Research Laboratory of Public Health 34, 297-298.

Ushiyama, K., Nagai, F., Nakagawa, A., Kano, I., 1992. DNA adduct formation by o-phenyphenol metabolite in vivo and in vitro. Carcinogenesis 13, 14691473.

WHO, 2003. 2-Phenylphenol and its sodium salt in drinking-water. Background document for preparation of WHO Guidelines for drinking-water quality. Geneva, World Health Organization (WHO/SDE/WSH/03.04/69).

Wick, L.Y., Gschwend, P.M., 1998. Source and chemodynamic behavior of diphenyl sulfone and ortho- and para-hydroxybiphenyl in a small lake receiving discharges froman adjacent superfund site. Environmental Science \& Technology 32, 1319-1328. 